\title{
INNOVATIVE USE OF THE POTENTIAL OF CONTEMPORARY SENIORS
}

\author{
Magdalena Urlińska \\ Academy Ignatianum in Cracow, Poland
}

\begin{abstract}
Attitude to old age varies depending on the cultural context - historical, like changing the public perception of the elderly and attitude to senior age. Since the 60s of the twentieth century in sociology is functioning the concept of ageism, describing the phenomenon of discrimination against older people because of their age. It manifests itself in a dismissive ratio deficits on offer for seniors or problems in the labor market. Social stigmatization of seniors has a direct impact on their physical and mental health. Sense of control over their own lives and to have a sense of whether the purpose is of great importance at the end of professional activity. Halting the process of marginalization of the elderly multifaceted and complex solutions, parallel, integrated actions legal, financial, educational and psychological. Exploiting the potential which lies dormant in this social group gives positive changes. It becomes an element of counteracting the social stigma of old age, disenchant way of looking at modern senior. This scope for lifelong education, which is a bailout. It creates an action for the activity, gives the opportunity to make changes, positive transgression in the senior phase.
\end{abstract}

Actions and initiatives designed to help them adapt to changing social reality and the market, they combine traditional teaching methods (lecture) with active methods (including mentoring). It is used in the process a wealth of experience as seniors. When preparing an offer of educational activities worth including senior-leadership initiatives. This seniormentoring build on the expertise provides a wide range of knowledge about man and the surrounding reality, by which it is possible to transpose this knowledge from theory into practice. Flexibility in the method is adequate to the problems and needs of seniors, can properly select and modify rules educational activities, so that they are the optimal solution. Senior-mentoring can serve the liberation of spontaneous being and becoming elderly, activating its development opportunities and a nap in her creative potential. Comprehensive measures to help people in late adulthood in the learning process, to acquire new knowledge in the field of self-development and improved skills are an opportunity to make fuller use of the life and free time.

Education towards old age, conducted in the form of mentoring, is based on an individual plan of action, which in effect allows tame old age, it helps to find the meaning of life, develop a model of relationships with significant others, develop defenses and adaptation to difficult situations or emergencies, find in new roles. Senior-mentors, they could play an advisory role, on the one hand would indicate assisting the elderly, preventing their social exclusion and pathological aging, on the other hand, monitor and assist the process of education for old age.

Keywords: adult education, education toward old age, lifelong learning, non-formal education, old age, positive aging, senior mentoring, space of educational activities. 


\section{Introduction}

Depending on the cultural and historical context, public perception of the elderly and attitude towards senior age are changing. In the past, social position of older people was much higher than today. Seniors were entrusted with the highest authorities. Their extensive experience and knowledge were invaluable support. Since the 60 s of the twentieth century, social scientists began to notice a phenomenon called ageism. It means an unequal treatment on grounds of age. This phenomenon is due to the direct prejudices and stereotypical belief that people in late adulthood are not able to perform certain their social roles. Social stigmatization of seniors directly affects on their physical and mental health. It often causes that they withdrawal from social and family life. The process of marginalization of the elderly should be suppression but it requires various actions and application of comprehensive solutions.

The problem of activation of the 50+ people occurs in all European countries. This situation requires from the government to make some changes in social policy, in the labor market, but also there is need to overcome social and mental barriers. The hardest thing is to convince society that the extension of the economic activity of people over fifty years old can brings positive changes and it will be beneficial for whole society. Change in the situation of today's seniors requires a parallel, integrated actions in the field of law, finance, education and psychology (Adamiec, 2012). The areas of contemporary senior's life are a space of influences, but also they are a challenge for modern lifelong education. The main purpose of education is to educate the people in late adulthood, that the seignioral age does not mean stagnation, sadness, uselessness and live from hand to mouth. It can be a time for self-realization, positive change, it may be a source of satisfaction. One of the forms of non-formal education, a way of activating the development a creative potential hidden inside an older person, is mentoring. Mentoring initiatives and actions are designed to valorising the phase of old age. This means that the old age has been given a new or revitalized value through reorganization of social life and change in the social perception of old age.

\section{Education towards old age}

European society is aging, so in the near future age management will become one of the most important specialization which can help maintain or even increase the productivity of advanced age workers. Creating jobs for mature and experienced workers 50+ allows to use the potential of people during the middle and late adulthood. Promoting solidarity between generations, 
encouraging diversity and creating a friendly atmosphere in the workplace, they are a manifestation of corporate social responsibility.

The human aging process effects on the quality of life, both in biological and psychological meaning. According to the concept of seasons of life of adults by Daniel Levinson, an adult individual's life flows to the rhythm and patterns of life that are common to people from different cultural backgrounds (Trempała, 2000). Both, performed social roles, the quality and type of relationship, but also personality traits, make that the course of life becomes an individualized process. However, it can be distinguished the universal values prevalent in different cultures. In the postmodern society old age coincides with the moment of retirement. Qualitative changes in the lives of seniors occur not only in the professional sphere. It changes their social position too. There are redefined roles in society. These changes are also reports in relationship with in the family. Children of seniors leave home, set up their own families, begin paid work, so as a result the family ties are loosened.

When seniors do not have time to adapt to old age, not get used to the new situation, it can become a source of tension and anxiety. The truth is that not every older person can handle on its own with these emotions. Having excess undeveloped time and the lack of a plan for the immediate future, in effect translates into mental condition seniors. At the seigniorial age is changed the culture of free time (Zalewska, 2010), but also it is changed the relationship with life partner. The new model of life or new living environment entails qualitative changes in the senior's everyday life. Retirement, which was to be anticipated period of rest, becomes a source of stress, transfers directly on the physical and mental state of senior. Deteriorating health condition, financial, social position of elderly person becomes reduced. The feeling of loneliness and misunderstanding, lack of sense of life, lack of plans and goals, this all makes that consequences are being felt by seniors but also by other members of society.

Seniors often have no awareness that physical deficits are compensated with development of crystallized intelligence, which has a growing tendency in the late stages of life. This is the result of learning and continuous training of the mind. An elderly person uses the resources accumulated over a lifetime. It is up to the individual interests and activities, however, it depends on whether the senior will be able to exploit this potential. Using of its own intellectual resources, is a chance for the long human activity. It does not limited the need for continual learning or diminish of curiosity. What favors the adaptation to old age is a positive attitude towards it, optimism and activity. From individual coping strategies in the next period of life it depends how will look like the old age, what will have the character and course (Oles, 2011). This is a field of action for lifelong education, which has aid character. 
The process of learning of people in late adulthood has profound significance for the development of their individual and society. Non-formal and informal education allows individual to customize the process to place and expectations, what is more, the subject is enabled in the planning of educational activities. Lifelong education creates a space for action activity which gives the opportunity to make changes, positive transgression in every phase of human development. Exploiting the potential which lies dormant in the social group of seniors, it gives positive changes, becomes an element of counteracting the social stigma of old age, creates new image of modern senior. Modern actions and initiatives dedicated to seniors, combining traditional teaching methods (lecture) with active methods (such as workshops, training sessions, group work, moderation or mentoring. They are not only attractive way of spending time, but most of all an opportunity for a better adaptation of seniors to the changing social reality and the labor market.

Learning in the period (middle and late) adulthood has gained a new meaning today. Adult participants of educational activity know what they want to learn and what is important to them. They are looking for sources of knowledge and authority, ipso facto taking responsibility for their own learning process. The idea of lifelong education fits the needs of modern seniors, who often have no idea for the management of their time after retirement. An important for quality of life is to make society more aware of the fact that seniors have experience and accumulated knowledge, which can give to society. The old people have untapped potential and energy reserves, which skillfully activated can give the old people a new quality, gives them chance to have more satisfying life. It is a challenge for education, the labor market and authorities. Reflects of changes in social consciousness are national and local programs, many initiatives which function as supporting the activity of seniors.

Change requires individualized actions, appropriate education, working with modern seniors, but also with people during middle adulthood. They have to be prepared for new roles, aware of possible paths of development that allowed them to adapt to a rapidly changing world and society. Prevention may be e.g. adopting of proper lifestyle, working out in own strategy, specific habits and skills to cope with new social roles. On the market there is no lacking of offers which are dedicated towards seniors. But mostly, they are directed to a small group of people who knows exactly what they are looking for. They can reach the proposals and choose the most suitable for themselves. The problem is a group of seniors who doesn't fully aware of their own potential, have a real problem with identifying their interests and an excess of free time, which cannot alone fill in the content. The practice of everyday life building „bottom-up" the social capital of the elderly. Creating situations and events involving seniors in cultural, artistic, educational, sports or volunteer activities, encouraging them to 
participate in social life can be a great opportunity to help them in establishing proper interpersonal relationships. That all gives older people a sense of being needed, a sense of happiness and life satisfaction. Banks time, book clubs, interest clubs, religious groups, Universities of the Third Age are examples of how seniors can appealing and efficient spend their free time. Unfortunately, these initiatives are still more like an experiment than regular activities in social policy.

The condition for success is to develop in seniors certain habits and skills that will allow them mentally adapt and adjust to retiring. The plans, which are made for the future by pensioners, are mainly related to planning leisure time. They want to share more time with their families and friends or spend time on activities related to the readership or gardening. Rarely seniors set a goal of selfdevelopment, of broadening their own horizons or the realization of dreams. Activities and educational initiatives dedicated to the elderly focus on aspects such as: education for culture, information technology, civic education, creativity and health prevention. Today increasingly the internet platform is becoming a tool of social change. It is now daily communication space. Older people are increasingly willing to learn new forms of communication, because it gives them the opportunity to reach to the group with new contents and offers (including educational offers). All forms of communication are building and maintaining relationships with the community, gives seniors a sense of integration which allows them to share the experience with others. One of the forms of lifelong learning in the seigniorial period of life can be e-coaching (understood as teaching, assistance, providing advice ward, building relationships based on trust, with using the Internet). The opportunity to be part of the network society prevents social exclusion of seniors. Knowledge of new technologies gives seniors unlimited access to information and materials without leaving home. Overcoming their own limitations (physical and intellectual) contributes to improving the quality of life of seniors. Internet gives them a tool to communicate with loved ones (especially in a situation of migration senior's children), it allows them to maintain social ties or participate in family life, despite the distance. Via the Internet the elder people can make new friends, take advantage of the offers, develop and share their passions and thoughts.

The speed and extent of aging is determined by factors such as social conditions, individual predispositions units defined character traits, health condition, lifestyle, certain habits. Seniors' conscious decisions and choices, taken in the context of their own biography and broadly defined health are crucial for the well-being (Koziel et al., 2008). Sense of control over seniors own lives and to have a meaning of life is of paramount importance aim for older person, not only during its working lives, but also afterwards. A manifestation of responsibility seniors for their own lives, for old age, is the 
need for the activity and willingness to participate in social life. Maintaining social ties gives meaning to existence, it can enter into new social roles, easier to deal with the deficits associated with age and traumatic events. Public participation is an expression of self-creation in late adulthood, is a symptom of the process of healthy aging, which translates directly to quality of life and wellbeing of seniors (Bee, 2004; Pietrasiński, 1990; Steuden, 2012).

\section{Mentoring as an innovative method of working with senior}

Mentoring is one of the forms used in lifelong education. It is the teaching, helping to overcome adversity, providing advice and support, is a method of improving the ability of independent and responsible for achieving targets. Mentoring is a concern for self-development and reflective approach to individual own biography. It is synonymous with motivation, encouragement to overcome the barriers inherent in man, to increase its productivity and develop a key competences essential for the development. Mentoring relationship contributes to building self-confidence in an older person. It explores its own potential and the meaning of life. Professional help from person they can trust and who knows their needs with the phase of their lives, that is needed support for people in late adulthood. Working with the senior with mentor, the selection of the strategy would depend on the sense of control, internal motivation, the prospects for the future, optimism and a set of values preferred by senior.

The basic premise of mentoring is to work with dependents, based on the plan approved by senior personal development. Mentoring work is focused on discovering and developing the potential of the mentees, stimulating and motivating to act, supporting self-development. Both professional and personal development, is associated with continuous improvement of your competence, with acquiring new skills, analyzing and interpreting lived experiences. The ability to self-realization of the goals and the desire to act requires support from more experienced people who have necessary knowledge, skills and competencies. Mentoring situation is similar to the situation of the advice. It is a meeting of individuality. In a particular space and time comes to cooperation. The main aim of this cooperation is to determine a direction of the desired changes (Czerkawska, 2012). Whole activities under the mentoring relationships tend mainly to self-realization and self-development.

Mentoring relationships based on partnership. It is organized, voluntary meeting aimed at mobilizing the subject of educational activities (in this case, senior) and his creation of the right atmosphere and conditions for selffulfillment and self-development. Participant in educational activities becomes responsible for its learning process and decisions. However, in this process senior needs a specific support. It is an area of senior-mentor activities. Senior- 
mentor will be a person who accompany an elderly person in the investigation into the truth about itself. This kind of personal guide supports and influences on senior' $s$ educational process, creates a favorable environment for selfdevelopment, arouse in an older person a desire to independent learning. Seniormentor inspiring and motivating ipso facto reinforces in an older person the sense of agency, control over its own live, a sense of self-worth.

Therefore the aim of the senior-mentoring would be comprehensive measures to support people in late adulthood in the learning process, to acquire new knowledge in the field of self-development and improvement of skills that will allow them to get more out of life and free time. Individual work with the senior-mentor can identify preferred learning style by an older person. Among practical implications of the senior-mentoring it can be specify as: getting acquainted with senior's learning motivation; encouraging in self-education, using senior's life experiences and skills; analyzing the positive and negative experiences from all sphere of life; encouraging to make reconstruction of individual life history; strengthening the reflectivity with regard to the life course, events and achievements; stimulating creative potential, curiosity about the world and people; assisting in determining the next goals and tasks, which can be in the future a source of life satisfaction. The senior-mentor should accompany the old person in its aging process. That is why in this mentoring relationship he/she should take on a role of: a leader, a counselor, a guide, a teacher, a tutor, an expert with highly professional and social qualifications. It should be a person who can share its knowledge, experience to creates a new perspective and helps older people finding alternative solutions for their problems. Senior-mentor should know how to discover seniors' skills and passions, teach them how to control emotions and behaviors.

Pattern of the old age phase includes professional activity (extended through continuing education and mobilization programs for employees 50+), active citizenship (participation in social life, engaging in pro-seignioral's and intergenerational initiatives), healthy lifestyle (prevention and psychological support), financial independence (disposal funds providing social and health security) activities delaying the aging process (broadly defined proactive lifestyle), and building a correct relationship and participation in the circle of family and friendly.

Among the determinants of life satisfaction it can be exchange: internal harmony, meaningful activity, the implementation of goals, sense of agency, happiness, belonging and self-development. The mental welfare is largely determined by personality traits (specific competencies, attitudes, behaviors, habits, social skills, or subjective sense of health). The most important factor of personality is considered ego resiliency. It refers to the maintenance, revitalization and improvement of mental and physical functioning of the 
individual in relation to new challenges. In a direct way it impacts on the physical fitness, mental well-being, quality of interpersonal relationships and the level of involvement in an elderly person. Locus of control of life, belief in selfefficacy, the ability to anticipate events and plan activities allows seniors to maintain a sense of security and inner peace. They begin to believe that they are able to cope with the changing life situation.

Senior-mentoring can be a proposal to work with people both in middle age and late adulthood. Jointly developed solutions allow people to fill the mental emptiness (e.g. an empty nest syndrome or a mid-life crisis) and also it is alternative management of free time. Solutions allow to form goals, lay out new paths of development, help to rediscover in the modern world. It contributes to build and strengthen interpersonal relationships, establish deeper social ties, encourage to take responsibility for seniors own lives and make decisions without fear and concerns that they will not handle with problems. An important issue in the mentoring process is a high level of motivation of educational units, the orientation of life and the belief that educational activities are a tool for the implementation of plans and development tasks. People in seigniorial aged are in the privileged position. In contrast to the younger generations, they are exempt from many duties, shall not be subject to numerous limitations associated with taking on their social roles. They have the time and opportunity to participate in educational activities, it just depends on them.

„Old age does not necessarily mean passivity, resignation, everything. On the contrary - suggests such life goals, and such opportunities, which vainly sought in the earlier stages of life ,(Łosiewicz, 2004). Many seniors looking for their own formulas, including educational. They are people who are full of passion, energy, willingness to act and to share their experience. They often provide assistance, practicing active lifestyle in its various forms. They have the time and they are opened to new experiences, but sometimes they are not aware of their potential, they don't believe in themselves. This group needs especially senior-mentor help. A person of senior-mentor don't need to be necessarily younger than the participants of the mentoring process. A better solution would be to use the experience and competence of person in the middle or late adulthood, who arouse more trust in seniors and becomes quicker an authority for them, because they like no one else understands changes related to the phase of life. These senior-leaders, much easier than younger people, will be able to establish relationships with the older participants of mentoring process. They will perfectly understand the emotional and spiritual needs, expectations and limitations of people in seigniorial age.

It would be worth to create in a social space workplace for well-educated senior-mentors, who would have the task to show older people how to learn, how to effectively search for and use information in order to solve the problems. 
Senior-mentor would combine within its competence function of social and educational mentor. On the one hand, senior-mentor would indicate support for the elderly, preventing their social exclusion and pathological old age. On the other hand, he/she would monitor and assist in the process of education for the old age. Senior-leaders / senior-mentors along with seniors take actions and initiatives concerning on heritage of the region, the production of goods or services for seniors. The initiatives, which include senior leaders in the programs, can bring very good results. Senior-mentoring which will be built on the expertise undoubtedly will have several properties. It will based on extensive, but a detailed knowledge about individual and the surrounding reality (it will give a chance to transpose knowledge from a theory into a practice). The flexibility of approach to the problems and needs of seniors can be properly selected and modified the rules of an educational activities. In the context of pragmatic application solutions it will be a procedural knowledge, focused on the search for alternative ways to solve problems, the formation of accurate applications, allowing senior has the opportunity to develop a personal strategy to cope with new, often difficult situations. Creating a network of professionally trained senior-mentors would attempt to meet the expectations of the older people. Each senior, who will work with mentor, would gain an access to new services, will has an individual plan of action adapted to individual needs.

Practical implications of the senior-mentoring will be inextricably linked with the concept of lifelong education. Adapting to rapidly changing world, requires from seniors an extraordinary flexibility, openness, willingness to take risks and new challenges. Therefore, it is not only the domain of the young people. Education towards old age, conducted in the form of mentoring, will be based on an individual senior's plan of action. In the effect it will allow for tame the old age, help to find the meaning of life, develop a model of relationships with significant Others, develop defense and adaptation mechanisms towards difficult or crisis situations, help to find itself in new roles.

\section{References}

Adamiec, J. (2013). Polityka przedtużenia aktywności zawodowej osób starych. In: Starzenie sie społeczeństwa polskiego (pp. 151-168). Studia BAS, 2. Downloaded from http://www.ceeol.com/search/article-detail?id=249312.

Bee, H. (2004). Psychology of human development. Poznań: Zysk i Spółka.

Błędowski, P. (2013). Aktywność zawodowa osób starszych. In: Kiełkowska, M. (Ed.) Rynek pracy wobec zmian demograficznych (pp. 52-63). Zeszyty Demograficzne. Warszawa: Efekt. Downloaded from http://www.instytutobywatelski.pl/wp-content/uploads/ 2013/09/Demografia_01.10.pdf 
Błędowski, P., Szatur-Jaworska, B., Szweda-Lewandowska, Z., \& Kubicki, P. (Ed.) (2012). Raport na temat sytuacji osób starszych w Polsce. Warszawa: Instytut Pracy i Spraw Socjalnych. Downloaded from http://senior.gov.pl/source/raport_osoby\%20starsze.pdf

Czapiński, J., \& Błędowski, P. (2014). Aktywność społeczna osób starszych $w$ kontekście percepcji Polaków. Diagnoza społeczna 2013. Warszawa: Drukarnia Braci Grodzkich. Downloaded from http://www.diagnoza.com/pliki/raporty_tematyczne/Aktywnosc_ spoleczna_osob_starszych.pdf

Czerkawska, A. (2012). O transgresji w edukacji dorosłych i poradnictwie. Edukacja Dorostych, 2, 93-109.

Kargulowa, A. (2006). Poradnictwo andragogiczne. Konsekwencje paradygmatycznego przesunięcia. In: Teraźniejszość - Edukacja-Człowiek, 2 (34).

Kozielecki, J. (2000). Koncepcje psychologiczne człowieka. Warszawa: Wydawnictwo Żak.

Kozieł, D., Kaczmarczyk, M., Naszydłowska, E., \& Gałuszka, R. (2008). Wpływ kształcenia w Uniwersytecie Trzeciego Wieku na zachowania zdrowotne ludzi starszych. Studia Medyczne, 12, 23-28.

Łosiewicz, A. (2004). O wyższości starości, Charaktery, 1 (84).

Mellibruda, L. Przestańmy używać słowa emeryci. To stygmatyzuje. Downloaded from http://natemat.pl/118217,leszek-mellibruda-przestanmy-uzywac-slowa-emeryci-tostygmatyzuje-ludzi

Oleś, P. (2011). Psychologia człowieka dorosłego. Warszawa: Wydawnictwo PWN.

Pietrasiński, Z. (1990). Rozwój człowieka dorosłego, Warszawa: Wydawnictwo Wiedza Powszechna.

Rysz-Kowalczyk, B., \& Szatur-Jaworska, B. (2004). Polityka społeczna wobec cyklu życia. Faza starości. In: Kowaleski, T., Szukalski, P. (Ed.). Nasze starzejace się społeczeństwo. Nadzieje i zagrożenia. Łódź: Wydawnictwo Uniwersytetu Łódzkiego.

Steuden, S. (2012). Psychologia starzenia się i starości. Warszawa: Wydawnictwo PWN.

Trempała, J. (2000). Modele rozwoju psychicznego. Czas $i$ zmiana. Bydgoszcz: Wydawnictwo Naukowe WSP.

Zalewska, J. (2010). Starość a przemiany więzi społecznych. Kultura i Społeczeństwo, 3, 131150.

Bannewicz, M. (2011). Coaching $i$ mentoring $w$ praktyce. Warszawa: Burda Publishing Polska.

Sidor-Rzadkowska, M. (Ed.) (2014). Mentoring: teoria, praktyka, studia przypadków. Warszawa: Oficyna Wolters Kluwer business.

Megginson, D., Clutterbuck, D., Garvey, B., Stokes, P., \& Garrett-Harris, R. (2008). Mentoring $w$ działaniu. Przewodnik praktyczny. Poznań: Wydawnictwo Rebis. 